\title{
Music Education in College Quality Education
}

\author{
Wenlong Ma \\ Xi'an University, Xi'an, Shaanxi, 710065
}

Keywords: music education; college quality education

\begin{abstract}
With the continuous development of China's educational undertakings and the continuous advancement of high-quality talent development plans, China's higher education has been greatly developed. The 21st century is the competition of talents, and the key to competition is the competition of talent quality. Music education is an important part of college quality education, and it is also one of the important forms of education for teaching higher education and cultivating comprehensive talents. This paper starts with the effect of music on college quality education and analyzes the role of music teaching in college education.
\end{abstract}

\section{Introduction}

Music education is an effective means and an indispensable aspect of implementing quality education. Music education is a kind of gymnastics, a purification agent of the soul. It can train and cultivate emotions and psychology to achieve the purpose of influencing people's aesthetic view, human outlook and values. In the content and development level of the decision-maker, in promoting the improvement of people's comprehensive quality, music education has unique functions that cannot be replaced by other education. Therefore, we must fully understand the position and role of music education in the quality education of the university, and strengthen the comprehensive education of the quality and reform the university music education.

\section{Music Education and College Quality Education}

First of all, music education is an important part of university quality education. Music is a universal art form that exists in our lives. Music is full of all aspects of our lives, so music education is an important component of university quality education. From the perspective of literary accomplishment, music education can effectively improve students' own cultural accomplishment, strengthen students' ability to master science and culture, and promote students' all-round development. From the perspective of cultural awareness, music education can be fundamentally Improve students' interest in history, humanities and science and technology, and improve students' self-learning ability; in terms of innovative ability, music education can fundamentally improve students' innovative ability and improve students' artistic innovation ability through artistic edification; In terms of aesthetics, music education can effectively improve students' artistic appreciation and strengthen their aesthetic ability according to their own characteristics. Therefore, music education is an indispensable part of university quality education. Secondly, music education provides a platform for the practice of university quality education. Quality education can comprehensively promote the development of students' comprehensive ability and strengthen students' physical and mental development. It is an extremely important teaching method and an indispensable element in the life of music students. Therefore, for university quality education, music education provides A good practice platform, so to a certain extent, music education can comprehensively promote the development of quality education. Finally, the role of music education in promoting the quality of college students. First, music education can effectively improve students' ability of thinking development, strengthen students' brain development, improve students' artistic aesthetic ability, and strengthen the formation of students' comprehensive quality. Second, music education can improve students' personal charm and improve their personal charm. Comprehensive quality. Music education can promote students' self-cultivation and temperament 
formation, improve their personal charm in the process of interpersonal communication, continuously expand the interpersonal relationship of students, effectively improve the comprehensive quality of students, and strengthen students' core competitiveness.

\section{The Current Lack of College Music Education}

With the continuous advancement of university education and teaching reform, university training has changed from a single talent training structure model to a comprehensive and high-quality talent training model, especially the demand for talents in today's social market. All-round high-quality comprehensive talents have Become a key factor in social competition. The current university education is a part of quality education, and music education, as an important part of university quality education, plays an extremely important role in improving the overall quality of college students. There are some shortcomings in the current university music education in providing the quality of university students. The specific manifestations are as follows:

Compared with ideological and political education and professional course education, the proportion of music in university education in the professional teaching of non-music majors is relatively low. Especially in some non-art schools, the curriculum of music education is mostly elective courses, and some majors do not even have music appreciation courses. The quality training of college students focuses on ideological and moral courses and professional courses. For non-professional courses, such as sports, fine arts and music, the university management class does not have sufficient ideological understanding and lacks rationality in the curriculum arrangement. Although the quality education of university education has been implemented, some colleges and universities still focus on the skills training of students, ignoring the cultivation of students' comprehensive quality. Music education is an art education, art education requires professional textbook guidance and systematic theoretical guidance, while college music courses, especially some non-artistic music elective courses, due to curriculum arrangements, etc., there is no professional music teaching materials. Some music teachers are not born in the class. Music courses are mainly music appreciation. The creation and analysis of music are not carried out in depth, and there is no systematic theoretical system.

\section{Strategies to Strengthen Music Teaching and Improve the Quality of College Students}

Build a systematic music quality teaching course. In the process of teaching music courses, there is a lack of certain standardization, and there are certain drawbacks. The music curriculum should be scientific and standardized, and fully integrated into the connotation of quality education. First, strengthen the emphasis on college students' music appreciation courses. In the process of music education, music appreciation teaching is an extremely important teaching method, which can effectively improve students' comprehensive quality ability. Music appreciation class can effectively improve students' musical interest, broaden students' musical perspective and enhance students' musical feelings. In the current stage of university teaching, the students' music foundation is weak. Some difficult music skills training is not suitable for them. It is easy to cause their rebellious psychology and increase the difficulty of music education. Therefore, from the perspective of students We will offer music appreciation classes to enhance students' music based knowledge management. In the music appreciation course, we should select different kinds of excellent music works from ancient to modern, rich in music knowledge content, improve students' feeling ability and understanding ability, and finally achieve the fundamental purpose of improving students' music literacy and strengthening students' quality education. In the process of music appreciation class, it is necessary to fully combine the students' own characteristics, improve students' music language and thinking, stimulate students' emotional resonance, improve students' imagination, and full up the music works to create a three-dimensional music image. In the process of listening to music, teachers should integrate according to the information of music works, conduct a comprehensive analysis of music works, conduct effective evaluation, expound their own opinions, encourage students to express their own opinions, and effectively improve students' logic. Thinking 
ability and innovative thinking ability, effectively improve students' aesthetic ability and enhance students' comprehensive quality ability. Second, increase the setting of ethnic folk music lessons. There are many kinds of national music in our country, which fully highlights the characteristics of the Chinese nation and has a very high artistic quality. Therefore, in the process of university quality education, it is of certain significance to improve the setting of the national music curriculum. Through the study and appreciation of ethnic music, students can fully explore our long history and civilization, improve national pride and cohesiveness, and improve students' patriotism. It has extremely special significance for promoting the formation and development of contemporary college students' outlook on life, world outlook and values.

Improve the overall quality of university music teachers and strengthen the quality of teachers' moral education. The most important part of music education in university quality education is to improve the professional music level of university teachers and their cultural qualities. Today, in the depth of quality education, there is a high demand for the overall quality of university teachers, but there are still some educational disadvantages at the current stage of university teachers. Therefore, it is necessary to strengthen the construction of university music teachers, improve the professional level and cultural quality of university music teachers through training and further study. At the same time, it is necessary to strengthen teachers' own moral education quality. The first is to change the moral education concept of university music teachers. Improve the morality and values of music teachers.

Music education is an art education, and also a window for students' emotional venting. Especially in today's highly competitive learning environment, music can play a good role in decompression, and at the same time improve the overall quality of college students in the subtle. For the role of music education, schools should have a full understanding and make the music curriculum more reasonable in the curriculum. In addition, it is necessary to increase investment in music education, such as the construction of multimedia and the construction of music equipment, all need the support of the school. Music is an art class and a professional and systematic form of education. In music education, the leading role of teachers is very important. The school is extremely important for the training of music teachers. On the one hand, music teachers should improve their independent learning ability. On the other hand, through the professional training of the school, music teachers can systematically build a music system and improve their professional quality. For music elective courses, the school should provide professional music materials. At present, college students' music textbooks are written by university teachers. Therefore, for the selection of music textbooks, we must first select professional and targeted textbooks. In addition, standardized procurement should be adopted for music teaching materials. The preparation of teaching materials should be prepared by professional teachers in order to ensure the quality of teaching materials.

\section{Conclusion}

Music education has certain educational significance in the current stage of university education. It can effectively improve students' music literacy and improve students' artistic ability. Music education can promote students' all-round development and effectively practice college students' quality education. College music education is one of the important forms of education to improve the overall quality of college students. College music education plays an important role in cultivating students' aesthetic concept, cultivating students' creativity and cultivating students' emotional quality. Therefore, music education is extremely important for the improvement of the quality of college students and the harmonious and healthy development of students.

\section{References}

[1] Li Xiaojie. On the role of music literacy in the ideological political education [J]. Jin Tian, 2013 (08). 
[2] Zhang Xuena. The importance of opening music science in engineering colleges [J]. North Music, 2013 (04)

[3]Yang Guihua. Strengthening the Importance of College Students' Music Aesthetic Education [J].Journal of Southwest University for Nationalities (Humanities and Social Sciences) 2013(2).

[4] Liang Na. Research on the Theory and Practice of Vocal Music Elective Courses in Colleges and Universities [D]. Capital Normal University, 2010(5) 